\title{
Cocaine Abuse in Humans Is Not Associated with Increased Microglial Activation: An 18-kDa Translocator Protein Positron Emission Tomography Imaging Study with $\left[{ }^{11} \mathrm{C}\right] \mathrm{PBR} 28$
}

\author{
Rajesh Narendran, ${ }^{1,2}$ Brian J. Lopresti, ${ }^{1}$ Neale Scott Mason, ${ }^{1}$ Lora Deuitch, ${ }^{1}$ Jennifer Paris, ${ }^{2}$ Michael L. Himes, ${ }^{2}$ \\ Chowdari V. Kodavali, ${ }^{2}$ and Vishwajit L. Nimgaonkar ${ }^{2,3}$ \\ Departments of ${ }^{1}$ Radiology, ${ }^{2}$ Psychiatry, and ${ }^{3}$ Human Genetics, University of Pittsburgh, Pittsburgh, Pennsylvania 15213
}

\begin{abstract}
Basic science investigations have consistently shown that repeated exposure to psychostimulant drugs, such as cocaine, activate the immune response and lead to inflammatory changes in the brain. No previous in vivo studies have confirmed this observation in chronic cocaine-abusing humans. To test this hypothesis, we used positron emission tomography imaging to measure the binding of $\left[{ }^{11} \mathrm{C}\right] \mathrm{PBR} 28$ to the $18 \mathrm{kDa}$ translocator protein (TSPO), a marker for microglial activation in a group of 15 recently abstinent cocaine abusers and 17 matched healthy controls. $\left[{ }^{11} \mathrm{C}\right]$ PBR28 volumes of distribution expressed relative to total plasma ligand concentration $\left(V_{T}\right)$ were measured in subjects with kinetic analysis using the arterial input function. Subjects were also genotyped for the TSPO alanine147 threonine (Ala147Thr, rs6971) polymorphism that has been shown to influence the in vivo binding of PBR28 to TSP0. Consistent with previous reports, the TSPO Ala147Thr genotype predicted the in vivo binding of $\left[{ }^{11} \mathrm{C}\right] \mathrm{PBR} 28$. No significant differences in $\left[{ }^{11} \mathrm{C}\right] \mathrm{PBR} 28 V_{T}$ were observed in the cortical and subcortical regions in cocaine abusers compared with healthy controls. The results of this in vivo study do not support increased TSPO expression and, by extension, microglial activation in chronic cocaine-abusing humans. Further research with more direct markers of microglial activation is necessary to conclusively rule out neuroinflammation in cocaine dependence.
\end{abstract}

Key words: $\left[{ }^{11} \mathrm{C}\right] \mathrm{PBR} 28$; cocaine dependence; inflammation; PET; TSPO

\section{Introduction}

Positron emission tomography (PET) imaging studies have demonstrated decreased dopamine transmission in the striatum of chronic cocaine abusers relative to healthy comparison subjects (Volkow et al., 1997; Malison et al., 1999). These reports have been furthered with data suggesting that less dopamine release is associated with higher relapse rates in cocaine abusers (Martinez et al., 2007, 2011). One possible mechanism that contributes to decreased dopamine transmission in cocaine abuse may involve activation of microglia in the brain (Lee et al., 2009; Yao et al.,

Received March 5, 2014; revised June 9, 2014; accepted June 11, 2014.

Author contributions: R.N. and V.L.N. designed research; R.N., B.J.L., N.S.M., L.D., J.P., and C.V.K. performed research; R.N., L.D., M.L.H., C.V.K., and V.L.N. analyzed data; R.N. wrote the paper.

This work was supported by National Institute on Drug Abuse Awards R01DA026472 and R01AA0188330 and National Institute on Alcohol Abuse and Alcoholism to R.N., V.L.N. was supported by National Institute of Mental Health Awards R01 MH63480, R01MH09375, and D43TW008302. We thank Dr. Robert Innis, Molecular Imaging Branch, Division of Intramural Research Program, National Institute for Mental Health for bringing [ $\left.{ }^{11} \mathrm{C}\right]$ PBR28 to the University of Pittsburgh PET Facility. The content is solely the responsibility of the authors and does not necessarily represent the official views of the National Institute on Drug Abuse, National Institute on Alcohol Abuse and Alcoholism, National Institute of Mental Health, or the National Institutes of Health.

R.N., N.S.M., and M.L.H. have done contractual research work at the University of Pittsburgh for ONO Pharmaceuticals. The remaining authors declare no competing financial interests.

Correspondence should be addressed to Dr. Rajesh Narendran, Department of Radiology and Psychiatry, University of Pittsburgh, University of Pittsburgh PET Facility, UPMC Presbyterian, B-938, Pittsburgh, PA 15213. E-mail: narendranr@upmc.edu.

DOI:10.1523/JNEUROSCI.0928-14.2014

Copyright $\odot 2014$ the authors $\quad 0270-6474 / 14 / 349945-06 \$ 15.00 / 0$
2011). For example, inflammatory cytokines released by activated microglia (and astrocytes) have been shown to decrease dopamine synthesis and release by a variety of mechanisms, such as oxidization of tetrahydrobiopterin, a cofactor involved in the dopamine synthesis pathway; altering the expression and function of the vesicular monoamine transporter, Type 2 and dopamine transporter; and enhancing the production of kynurenic acid, which in turn decreases glutamate transmission and impacts dopamine release (for detailed review, see Felger and Miller, 2012). Little et al. (2009) investigated this issue in postmortem human brain tissue and reported a twofold to fourfold increase in activated microglia and macrophages in the anterior midbrain of cocaine abusers compared with controls. No previous in vivo studies have reported on whether or not there is an increase in activated microglia in the brains of cocaine abusers.

To evaluate this issue, we used $\left[{ }^{11} \mathrm{C}\right] \mathrm{PBR} 28$ and PET to contrast the in vivo status of the $18 \mathrm{kDa}$ translocator protein (TSPO) in 15 cocaine abusers and 17 healthy comparison subjects matched for age, gender, race, and nicotine smoking status. TSPO, which is a high-affinity cholesterol transporter located in the mitochondrial membrane of steroid-producing cells, is an ideal target because it is upregulated in activated microglia in inflammation (Imaizumi et al., 2007; Ching et al., 2012). Thus, increased TSPO binding in cocaine abusers would indicate greater activated microglia and triggering of the inflammatory 
cascade of the brain. Furthermore, the localization of increased TSPO in brain regions, such as the midbrain, striatum, and prefrontal cortex, which are part of the mesolimbic dopaminergic pathways and implicated in addiction, would suggest a role for inflammation in decreased dopamine transmission in cocaine dependence.

\section{Materials and Methods}

Human subjects. Thirty-two subjects were enrolled in this study who were either cocaine abusers $(n=15)$ or healthy comparison $(n=17)$ subjects. The study was conducted following the approvals of the University of Pittsburgh Institutional Review Board and Radioactive Drug Research Committee. All subjects provided written informed consent. Cocaine abusers were recruited through flyers displayed at local community centers, buses, and addiction medicine clinics. Study criteria for cocaine abusers were as follows: (1) males or females between 18 and 55 years of age, of all ethnic and racial origins; (2) fulfill DSM-IV criteria for cocaine dependence as assessed by SCID; (3) a positive urine screen for cocaine; (4) no DSM-IV Axis I disorder other than cocaine abuse or dependence, including abuse or dependence to alcohol or other drugs (nicotine dependence was allowed); (5) no current (as confirmed by urine drug screen at screening) use of opiates, cannabis, sedative-hypnotics, amphetamines, MDMA, and PCP; (6) not currently on any prescription or over-the-counter medications; (7) no current or past severe medical or neurological or infectious illness as assessed by a complete medical assessment, which included a review of past medical records, complete physical examination, electrocardiogram, blood and urine tests; (8) not currently pregnant; (9) no history of significant radioactivity exposure (nuclear medicine studies or occupational exposure); and (10) no metallic objects in the body that are contraindicated for MRI. All eligible cocaine-dependent subjects completed a minimum of 14 days of outpatient abstinence monitored with witnessed urine toxicology (all subjects underwent urine drug screens for cocaine and other recreational drugs 3 times per week for 2 consecutive weeks) before the PET scan. Healthy control subjects with no past or present neurological or psychiatric illnesses, including substance abuse, underwent the PET scan as outpatients.

Image acquisition and analysis. Before PET imaging, a magnetization prepared rapid gradient echo structural MRI scan was obtained using a Siemens 3 Tesla Trio scanner for determination of regions of interest. MRI segmentation was performed using the automated segmentation tool implemented in the FMRIB Software Library version 4.0 (Smith et al., 2004)

Briefly, $\left[{ }^{11} \mathrm{C}\right] \mathrm{PBR} 28$ was synthesized using the methods reported previously (Briard et al., 2008). The maximum injected mass for $\left[{ }^{11} \mathrm{C}\right]$ PBR2 8 was restricted to $\leq 8.7 \mu \mathrm{g}$. PET imaging sessions were conducted with the ECAT EXACT HR + camera. After a transmission scan, subjects received an intravenous bolus injection of $\left[{ }^{11} \mathrm{C}\right] \mathrm{PBR} 28$ and emission data were collected for 90 min (Fujita et al., 2008). Arterial blood samples were collected for $\left[{ }^{11} \mathrm{C}\right] \mathrm{PBR} 28$ to derive a metabolitecorrected input function. After centrifugation of the samples, plasma was collected and activity measured in $200 \mu \mathrm{l}$ aliquots on a gamma well counter. Subsets of the samples $(1,2,4,10,20,40$, and $60 \mathrm{~min})$ were processed using high performance liquid chromatography for determination of the fraction of activity corresponding to the parent compound (Fujita et al., 2008). These measured parent fractions were then fitted using a Hill model (Gunn et al., 1998). The input function was then calculated as the product of total counts and interpolated parent fraction at each time point. The measured input function values were fitted to a sum of three exponentials from the time of peak plasma activity and the fitted values were used as the input to the kinetic analysis. The clearance of the parent compound $(\mathrm{L} / \mathrm{h})$ was calculated as the ratio of the injected dose to the area under the curve of the input function (Abi-Dargham et al., 1994). The free fraction of radiotracer in the plasma $\left(f_{P}\right)$ was determined by ultracentrifugation as described previously (Gandelman et al., 1994).

PET data were reconstructed and processed with the image analysis software MEDx (Sensor Systems) and SPM2 (www.fil.ion.ucl.ac.uk/spm) as de- scribed previously (Narendran et al., 2009). Frame-to-frame motion correction for head movement and MR-PET image alignment were performed using a mutual information algorithm implemented in SPM2. Cortical and subcortical regions of interest were restricted to those that are part of the mesolimbic dopaminergic pathways and implicated in addiction. These regions included the midbrain, limbic striatum (ventral striatum), associative striatum (the precommisural caudate, precommisural putamen, and postcommisural caudate), sensorimotor striatum (postcommisural putamen), dorsolateral prefrontal cortex, orbital frontal cortex, medial prefrontal cortex, anterior cingulate cortex, and medial temporal lobe (which included the amygdala and hippocampus). In addition, the cerebellum, a region that is relatively devoid of dopaminergic receptors, was included in the analysis as a control region. Cortical and subcortical regions of interest were defined on the MRI using a segmentation-based and direct identification method described previously (Abi-Dargham et al., 2002; Martinez et al., 2003). Regional volumes and time-activity curves were then generated in MEDx as outlined previously (Abi-Dargham et al., 2002).

TSPO availability was estimated using the PET outcome measure, $V_{T}$, which is total distribution volume expressed relative to total plasma ligand concentration (Innis et al., 2007). $\left[{ }^{11} \mathrm{C}\right] \mathrm{PBR} 28 V_{T}$ can be described as follows:

$$
V_{T}=f_{p} *\left(\frac{B_{\text {avail }}}{K_{D}}\right)+V_{N D}
$$

where $f_{p}$ is free fraction in the plasma, $B_{\text {avail }}$ is the density of TSPO receptors available to bind to $\left[{ }^{11} \mathrm{C}\right] \mathrm{PBR} 28, K_{D}$ is the equilibrium disassociation constant of $\left[{ }^{11} \mathrm{C}\right] \mathrm{PBR} 28$, and $V_{N D}$ is nonspecific binding. There is no reference region that is devoid of TSPO receptors that can be used to estimate and separate the nonspecific binding component from $\left[{ }^{11} \mathrm{C}\right]$ PBR28 $V_{T}$. However, this is less of an issue because $\sim 95 \%$ of $\left[{ }^{11} \mathrm{C}\right] \mathrm{PBR} 28 V_{T}$ in the brain has been shown to represent specific binding (Imaizumi et al., 2008). The TSPO Ala147Thr polymorphism has been shown to predict PBR28 binding affinity in human platelets and brain $V_{T}$ in a trimodal distribution (high $\mathrm{C} / \mathrm{C}$, low $\mathrm{T} / \mathrm{T}$, and mixed affinity $\mathrm{C} / \mathrm{T}$ binders) (Owen et al., 2010, 2012). Thus, all participants were genotyped so that it could be included as a factor in the analysis. The inclusion of genotype as a factor allowed for the detection of differences in TSPO density between cocaine abusers and controls.

DNA analysis. Genomic DNA from all subjects was isolated using QIAamp DNA Blood Mini Kits (QIAGEN), from whole blood samples stored in DMSO. The Ala147Thr SNP (rs6971) was assayed as described previously (Costa et al., 2009) Briefly, a PCR-amplified product was digested with NruI restriction enzyme according to the manufacturer's recommendations, and the digested products separated using $2 \%$ agarose gel electrophoresis. For quality control, $3 \mathrm{CEPH}$ samples were sequenced and used as positive controls.

Statistical analysis. Group demographic and baseline scan parameter (such as injected dose, mass, plasma clearance, $V_{N D}$ ) comparisons were performed with unpaired $t$ tests. Group differences in $V_{T}$ were analyzed using a linear mixed-model analysis with regions of interest as a repeated measure, and diagnostic group and genotype as fixed factors (IBM SPSS Statistics). Correlations between $\left[{ }^{11} \mathrm{C}\right] \mathrm{PBR} 28 V_{T}$ and clinical variables, such as duration and amount of money spent on cocaine abuse in addicts, were performed using Pearson Product moment correlation coefficient. A two-tailed probability value of $p<0.05$ was selected as the significance level for all analyses.

\section{Results}

Fifteen cocaine-dependent subjects ( 8 women and 7 men, mean age $39.9 \pm 9.0$ years) and 17 healthy comparison subjects ( 9 women and 8 men, mean age $38.4 \pm 8.1$ years) were enrolled in this study. Subjects were matched on both ethnicity (cocaine abusers: 8 black and 7 white; healthy controls: 8 black and 9 white) and smoking status (11 smokers/group matched on number of cigarettes smoked per day rounded to the nearest one-half pack, i.e., 10 cigarettes). The genotypes for the TSPO Ala147Thr 
Table 1. $\left[{ }^{11} \mathrm{C}\right]$ PBR28 PET scan parameters ${ }^{a}$

\begin{tabular}{lcc}
\hline Parameter & $\begin{array}{c}\text { Healthy comparison } \\
\text { subjects }(n=17)\end{array}$ & $\begin{array}{c}\text { Cocaine abusers } \\
(n=15)\end{array}$ \\
\hline Injected dose $(\mathrm{mCi})$ & $15.8 \pm 0.3$ & $15.6 \pm 0.7$ \\
Specific activity $(\mathrm{Ci} / \mathrm{mmol})$ & $3122 \pm 1556$ & $2731 \pm 1182$ \\
Injected mass $(\mu \mathrm{g})$ & $2.1 \pm 0.8$ & $2.5 \pm 1.7$ \\
Free fraction $(\%)$ & $3.4 \pm 0.8$ & $3.2 \pm 1.1$ \\
Clearance $(\mathrm{L} / \mathrm{h})$ & $100.0 \pm 35.8$ & $83.1 \pm 28.8$ \\
\hline
\end{tabular}

${ }^{a}$ Values are mean \pm standard deviation.

polymorphism that predicts PBR28 binding affinity were not significantly different in patients and controls (cocaine abusers: 8 $\mathrm{C} / \mathrm{C}$, high affinity, $5 \mathrm{C} / \mathrm{T}$, intermediate affinity, and $2 \mathrm{~T} / \mathrm{T}$, low affinity; controls: $12 \mathrm{C} / \mathrm{C}, 4 \mathrm{C} / \mathrm{T}$, and $1 \mathrm{~T} / \mathrm{T} ; \chi^{2}=1.12, \mathrm{df}=2, p=$ $0.57)$. These subjects were not preselected based on their genotype before the PET scans. The distribution of genotype was consistent with that reported in previously published studies when ethnicity is considered.

The cocaine abusers reported smoking crack cocaine on average of $17 \pm 7$ years and were spending $\$ 346 \pm 269$ weekly.

\section{Baseline parameters}

PET scan parameters are listed in Table 1. $\left[{ }^{11} \mathrm{C}\right] \mathrm{PBR} 28$-injected dose, specific activity at time of injection, and injected mass did not differ between the groups. No significant between-group differences were observed in the clearance rate of $\left[{ }^{11} \mathrm{C}\right] \mathrm{PBR} 28$ from the plasma compartment, or in $\left[{ }^{11} \mathrm{C}\right] \mathrm{PBR} 28 f_{P}$.

No significant between-group differences were found in the regions of interest volumes determined from the MRI scans (data not shown, all $p$ values $\geq 0.1$ ), suggesting lack of measurable volumetric changes in cocaine abusers.

\section{Measurement of TSPO availability}

As shown in Figure 1, significant differences in $\left[{ }^{11} \mathrm{C}\right] \mathrm{PBR} 28 V_{T}$ were observed with TSPO genotype, but not diagnostic group (linear mixed model: effect of diagnosis, $F_{(1,26)}=0.04, p=0.85$; effect of genotype, $F_{(2,26)}=14.72, p<0.001$; effect of region, $F_{(9,279)}=45.80, p<0.001$; genotype $\times$ diagnosis interaction, $\left.F_{(2,26)}=0.16, p=0.86\right)$. Excluding the low binders from the analysis (linear mixed model: effect of diagnosis, $F_{(1,25)}=0.35$, $p=0.56$; effect of genotype, $F_{(1,25)}=11.26, p=0.003$; effect of region, $F_{(9,252)}=57.32, p<0.001$; genotype $\times$ diagnosis interaction, $\left.F_{(1,25)}=0.22, p=0.64\right)$ or using $V_{T} / f_{p}$ as an outcome measure (linear mixed model: effect of diagnosis, $F_{(1,26)}=0.36$, $p=0.55$; effect of genotype, $F_{(2,26)}=11.61, p<0.001$; effect of region, $F_{(9,279)}=49.01, p<0.001$; genotype $\times$ diagnosis interaction, $\left.F_{(2,26)}=0.25, p=0.78\right)$ did not change the results.

Genotype-corrected correlation analyses revealed no significant associations between $\left[{ }^{11} \mathrm{C}\right] \mathrm{PBR} V_{T}$ in regions of interest and the duration in years, or amount in dollars of cocaine use.

\section{Discussion}

In this PET study, we failed to demonstrate increased $\left[{ }^{11} \mathrm{C}\right] \mathrm{PBR} 28$ binding to TSPO in cocaine abusers compared with matched healthy controls. Previous protein and gene expression data from animals have shown that repeated exposure to psychostimulant drugs, such as cocaine, activate the immune response and lead to inflammatory changes in the brain (for detailed review, see Clark et al., 2013). Based on these data and a postmortem study that reported an increase in activated microglia in the midbrain of chronic cocaine abusers (Little et al., 2009), we evaluated $\left[{ }^{11} \mathrm{C}\right] \mathrm{PBR} 28$ binding to TSPO in cocaine dependence. To the extent that TSPO expression is a valid marker for activated microglia in the CNS (Venneti et al., 2013), the results of this study do not support greater microglial activation in cocaine abusers. An important question, with respect to this negative finding, is whether [ $\left.{ }^{11} \mathrm{C}\right]$ PBR28 PET is sensitive enough to detect activated microglia in diseased conditions in humans. In the postmortem studies by Little et al. (2009), a twofold to fourfold increase in activated microglia and macrophages was observed in cocaine abusers compared with controls. Based on prior work that suggests a linear relationship between activated microglia/macrophages and TSPO expression (Venneti et al., 2008), this increase in cocaine abusers is within the twofold increase in TSPO specific binding reported in high-affinity binders compared with mixedaffinity binders (Owen et al., 2014). The fact that $\left[{ }^{11} \mathrm{C}\right]$ PBR28 can robustly distinguish binding $\left(V_{T}\right)$ between high- and mixedaffinity binders suggests that this radioligand is sensitive enough to detect the twofold to fourfold increase in activated microglia reported in postmortem cocaine brains. There are methodological differences that may have contributed to the discordant results between postmortem and human imaging studies. One such difference relates to the inclusion of the brains of cocaine abusers who were actively using cocaine before death as opposed to the inclusion of abstinent cocaine abusers in the imaging studies. Thus, the possibility of microglial activation reverting back to control levels after 14 days of abstinence cannot be ruled out from these imaging data. Another factor that may have contributed to increased microglia in postmortem cocaine brain samples relates to the medical cause of death, such as cocaine overdose, cocainerelated coronary spasm, and cerebrovascular events, acute trauma, etc., despite the best efforts to match control brains on this variable. Finally, the effect of comorbid drug and alcohol abuse in the postmortem cocaine sample, which is difficult to exclude using retrospective interviews, may be contributory as well.

The results of this study in cocaine abusers is in sharp contrast to a $\left[{ }^{11} \mathrm{C}\right] \mathrm{PK} 11195$ imaging study that reported a $264 \%, 313 \%$, and $1530 \%$ increase in TSPO in the midbrain, striatum, and orbital frontal cortex in methamphetamine abusers (Sekine et al., 2008). These results that show greater microglial activation in the mesolimbic dopamine pathway support a role for inflammation in decreased dopamine transmission in methamphetamine dependence. Nevertheless, the use of an unconventional modeling method to arrive at the PET outcome measure, binding potential in this study, limits the conclusions that can be drawn from this dataset. This relates to the use of a normalized $\left[{ }^{11} \mathrm{C}\right] \mathrm{PK} 11195$ time-activity curve from the cortex of healthy controls as a reference-tissue input function to model regions of interest in methamphetamine abusers. The problem with this approach is that it assumed that the nonspecific binding for $\left[{ }^{11} \mathrm{C}\right] \mathrm{PK} 11195$ is the same in controls and methamphetamine abusers. Such an assumption fails to account for any between-group differences that may exist in [ $\left.{ }^{11} \mathrm{C}\right] \mathrm{PK} 11195$ plasma parameters (e.g., metabolism, plasma clearance, and free fraction) and influx/efflux across the blood-brain barrier (e.g., kinetic rate constants $\mathrm{K} 1$ and $\mathrm{k} 2$ ), all of which can influence nonspecific binding. Typically, this issue is addressed in clinical PET studies by normalizing the region of interest specific binding in patients and controls to their respective total plasma concentration or reference region nonspecific binding. Furthermore, more recent $\left[{ }^{11} \mathrm{C}\right] \mathrm{PK} 11195$ studies in humans question the presence of a region of reference that is devoid of TSPO and uses clusters of brain voxels with the most rapid tissue clearance to represent nonspecific binding (Turkheimer et al., 2007). Thus, the possibility of specific binding 
to TSPO in the cortex leading to a biased between-group comparison in the Sekine et al. (2008) study cannot be ruled out either. We are not able to analyze the current dataset using the methods in Sekine et al. (2008) because $\left[{ }^{11} \mathrm{C}\right]$ PBR28 has no reference region that is devoid of specific binding. Also, the use of a normalized input function derived from controls to model both patient and control data, which exist in three different TSPO genotypes shown to predict $\left[{ }^{11} \mathrm{C}\right] \mathrm{PBR} 28 V_{T}$, would lead to assumptions that are further problematic. Another issue that deserves discussion, with respect to the discrepant imaging findings in chronic cocaine and methamphetamine abusers, is the fact that basic investigations consistently suggest greater toxicity to dopamine neurons from methamphetamine than cocaine administration (Ryan et al., 1988; Bennett et al., 1993). Consistent with this notion, rodent studies have shown increased microglial activation and neurotoxicity to dopamine nerve endings in the striatum after chronic methamphetamine, but not cocaine, administration (Thomas et al., 2004). Furthermore, human PET studies are consistent in reporting a reduction in striatal dopamine transporter, a marker that correlates with dopamine neurons, in abstinent methamphetamine but not cocaine abusers (Volkow et al., 1996, 2001; Wang et al., 1997). However, arguing against this is recent PET data that report lower striatal vesicular monoamine transporter, Type 2, which is a more stable and exclusively presynaptic dopamine neuronal marker, in abstinent methamphetamine and cocaine abusers (Johanson et al., 2006; Narendran et al., 2012). Further study of TSPO using rigorous imaging methodology is necessary to confirm the presence of microglial activation reported in methamphetamine dependence.

The strengths of this study are the inclusion of a relatively homogeneous sample of cocaine abusers with no comorbid medical, psychiatric, or drug abuse; monitored abstinence before imaging; the use of $\left[{ }^{11} \mathrm{C}\right] \mathrm{PBR} 28$, a well-validated secondgeneration TSPO radioligand with relatively high specific binding compared with $\left[{ }^{11} \mathrm{C}\right] \mathrm{PK} 11195$; documentation of TSPO genotype that influences in vivo binding; and use of compartmental modeling with an arterial input function to derive PET outcome measures. The limitations of the study are the generalizability of findings because individuals with $\mathrm{CO}^{-}$ morbid disorders were excluded; and inability to rule out between-group differ-
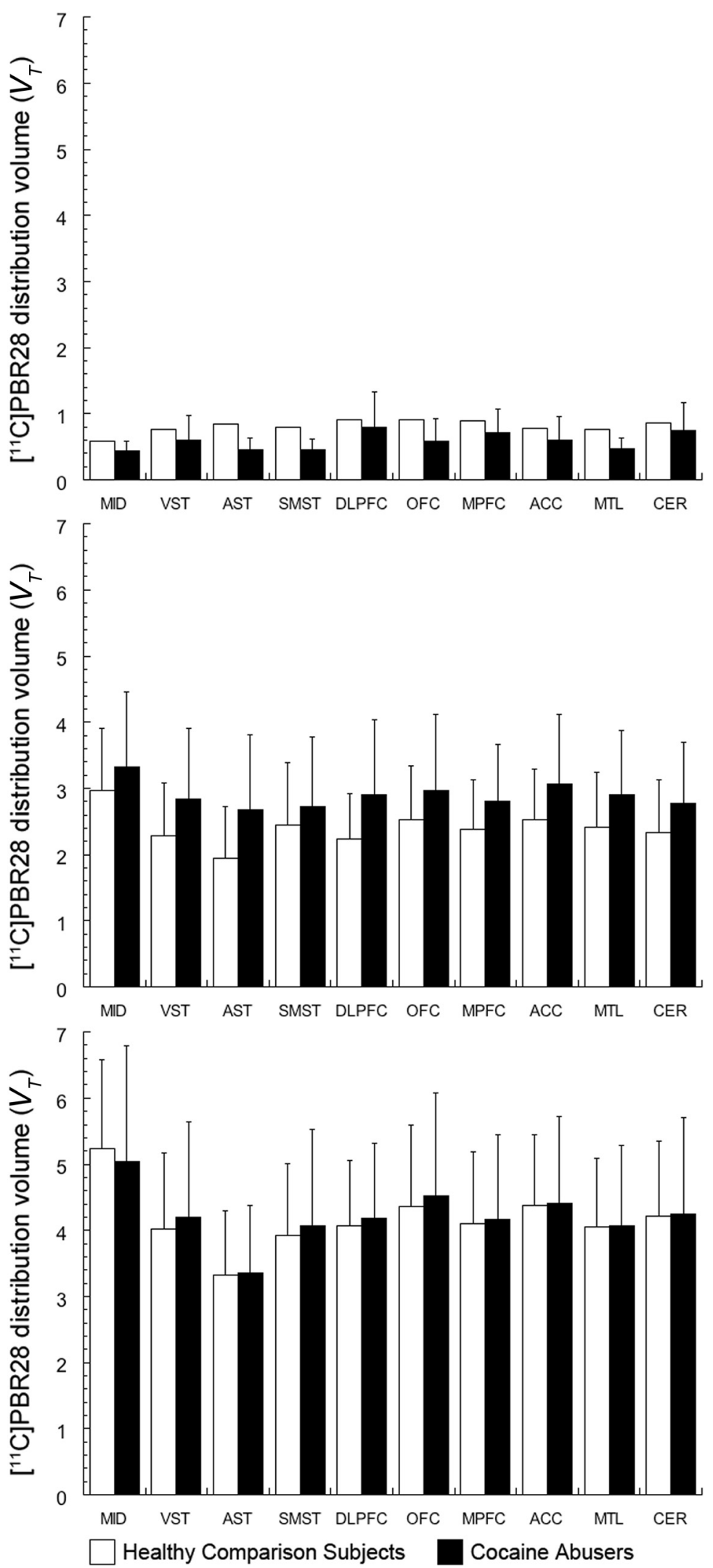

Figure 1. There is no significant difference in $\left[{ }^{11} \mathrm{C}\right] \mathrm{PBR} 28 \mathrm{~V}_{T}$ in cocaine abusers (black bars, mean \pm standard deviation) relative to healthy comparison subjects (white bars) in low- (top), mixed- (middle), and high-affinity binders (bottom). Consistent with prior reports, TSPO Ala147Thr (rs6971) genotypes predicted $\left[{ }^{11} \mathrm{C}\right] \mathrm{PBR} 28$ binding in vivo (low $<$ mixed $<$ high binders, i.e., $\left[{ }^{11} \mathrm{C}\right]$ PBR $28 V_{T}$ values in top $<$ middle $<$ bottom). Regions shown include the midbrain (MID), limbic striatum (VST), associative striatum (AST), sensorimotor striatum (SMST), dorsolateral prefrontal cortex (DLPFC), orbital frontal cortex (OFC), medial prefrontal cortex (MPFC), anterior cingulate cortex (ACC), medial temporal lobe (MTL), and cerebellum (CER). 
ences in $V_{N D}$ as a possible confound to increased microglial activation in cocaine abusers.

In conclusion, we found no differences in TSPO binding in brain regions that are involved in the mesolimbic dopamine pathway in cocaine abusers compared with controls. The results of these studies question the role of inflammation-mediated mechanisms in decreased dopamine transmission in psychostimulant addiction. Further studies with more direct markers for microglial activation are necessary to conclusively rule out inflammation in cocaine dependence.

\section{References}

Abi-Dargham A, Laruelle M, Seibyl J, Rattner Z, Baldwin RM, Zoghbi SS, Zea-Ponce Y, Bremner JD, Hyde TM, Charney DS, Hoffer PB, Innis RB (1994) SPECT measurement of benzodiazepine receptors in human brain with [123-I] iomazenil: kinetic and equilibrium paradigms. J Nucl Med 35:228-238. Medline

Abi-Dargham A, Mawlawi O, Lombardo I, Gil R, Martinez D, Huang Y, Hwang DR, Keilp J, Kochan L, Van Heertum R, Gorman JM, Laruelle M (2002) Prefrontal dopamine D1 receptors and working memory in schizophrenia. J Neurosci 22:3708-3719. Medline

Bennett BA, Hyde CE, Pecora JR, Clodfelter JE (1993) Differing neurotoxic potencies of methamphetamine, mazindol, and cocaine in mesencephalic cultures. J Neurochem 60:1444-1452. CrossRef Medline

Briard E, Zoghbi SS, Imaizumi M, Gourley JP, Shetty HU, Hong J, Cropley V, Fujita M, Innis RB, Pike VW (2008) Synthesis and evaluation in monkey of two sensitive ${ }^{11} \mathrm{C}$-labeled aryloxyanilide ligands for imaging brain peripheral benzodiazepine receptors in vivo. J Med Chem 51:17-30. CrossRef Medline

Ching AS, Kuhnast B, Damont A, Roeda D, Tavitian B, Dollé F (2012) Current paradigm of the $18-\mathrm{kDa}$ translocator protein (TSPO) as a molecular target for PET imaging in neuroinflammation and neurodegenerative diseases. Insights Imaging 3:111-119. CrossRef Medline

Clark KH, Wiley CA, Bradberry CW (2013) Psychostimulant abuse and neuroinflammation: emerging evidence of their interconnection. Neurotox Res 23:174-188. CrossRef Medline

Costa B, Pini S, Gabelloni P, Da Pozzo E, Abelli M, Lari L, Preve M, Lucacchini A, Cassano GB, Martini C (2009) The spontaneous Ala147Thr amino acid substitution within the translocator protein influences pregnenolone production in lymphomonocytes of healthy individuals. Endocrinology 150:5438-5445. CrossRef Medline

Felger JC, Miller AH (2012) Cytokine effects on the basal ganglia and dopamine function: the subcortical source of inflammatory malaise. Front Neuroendocrinol 33:315-327. CrossRef Medline

Fujita M, Imaizumi M, Zoghbi SS, Fujimura Y, Farris AG, Suhara T, Hong J, Pike VW, Innis RB (2008) Kinetic analysis in healthy humans of a novel positron emission tomography radioligand to image the peripheral benzodiazepine receptor, a potential biomarker for inflammation. Neuroimage 40:43-52. CrossRef Medline

Gandelman MS, Baldwin RM, Zoghbi SS, Zea-Ponce Y, Innis RB (1994) Evaluation of ultrafiltration for the free fraction determination of single photon emission computerized tomography (SPECT) radiotracers: b-CIT, IBF and iomazenil. J Pharm Sci 83:1014-1019. CrossRef Medline

Gunn RN, Sargent PA, Bench CJ, Rabiner EA, Osman S, Pike VW, Hume SP, Grasby PM, Lammertsma AA (1998) Tracer kinetic modeling of the 5-HT1A receptor ligand [carbonyl-11C]WAY-100635 for PET. Neuroimage 8:426-440. CrossRef Medline

Imaizumi M, Kim HJ, Zoghbi SS, Briard E, Hong J, Musachio JL, Ruetzler C, Chuang DM, Pike VW, Innis RB, Fujita M (2007) PET imaging with [11C]PBR28 can localize and quantify upregulated peripheral benzodiazepine receptors associated with cerebral ischemia in rat. Neurosci Lett 411:200-205. CrossRef Medline

Imaizumi M, Briard E, Zoghbi SS, Gourley JP, Hong J, Fujimura Y, Pike VW, Innis RB, Fujita M (2008) Brain and whole-body imaging in nonhuman primates of [11C]PBR28, a promising PET radioligand for peripheral benzodiazepine receptors. Neuroimage 39:1289-1298. CrossRef Medline

Innis RB, Cunningham VJ, Delforge J, Fujita M, Gjedde A, Gunn RN, Holden J, Houle S, Huang SC, Ichise M, Iida H, Ito H, Kimura Y, Koeppe RA, Knudsen GM, Knuuti J, Lammertsma AA, Laruelle M, Logan J, Maguire RP, et al. (2007) Consensus nomenclature for in vivo imaging of revers- ibly binding radioligands. J Cereb Blood Flow Metab 27:1533-1539. CrossRef Medline

Johanson CE, Frey KA, Lundahl LH, Keenan P, Lockhart N, Roll J, Galloway GP, Koeppe RA, Kilbourn MR, Robbins T, Schuster CR (2006) Cognitive function and nigrostriatal markers in abstinent methamphetamine abusers. Psychopharmacology (Berl) 185:327-338. CrossRef Medline

Lee CT, Lehrmann E, Hayashi T, Amable R, Tsai SY, Chen J, Sanchez JF, Shen J, Becker KG, Freed WJ (2009) Gene expression profiling reveals distinct cocaine-responsive genes in human fetal CNS cell types. J Addict Med 3:218-226. CrossRef Medline

Little KY, Ramssen E, Welchko R, Volberg V, Roland CJ, Cassin B (2009) Decreased brain dopamine cell numbers in human cocaine users. Psychiatry Res 168:173-180. CrossRef Medline

Malison RT, Mechanic KY, Klummp H, Baldwin R, Kosten TR, Seibyl JP (1999) Reduced amphetamine-stimulated dopamine release in cocaine addicts as measured by [123I]IBZM SPECT. J Nucl Med 40:110P.

Martinez D, Slifstein M, Broft A, Mawlawi O, Hwang DR, Huang Y, Cooper T, Kegeles L, Zarahn E, Abi-Dargham A, Haber SN, Laruelle M (2003) Imaging human mesolimbic dopamine transmission with positron emission tomography: II. Amphetamine-induced dopamine release in the functional subdivisions of the striatum. J Cereb Blood Flow Metab 23: 285-300. Medline

Martinez D, Narendran R, Foltin RW, Slifstein M, Hwang DR, Broft A, Huang Y, Cooper TB, Fischman MW, Kleber HD, Laruelle M (2007) Amphetamine-induced dopamine release is markedly blunted in cocaine dependent subjects and predictive of the choice to self administer cocaine. Am J Psychiatry 164:622-629. CrossRef Medline

Martinez D, Carpenter KM, Liu F, Slifstein M, Broft A, Friedman AC, Kumar D, Van Heertum R, Kleber HD, Nunes E (2011) Imaging dopamine transmission in cocaine dependence: link between neurochemistry and response to treatment. J Psychiatry 168:634-641. CrossRef Medline

Narendran R, Frankle WG, Mason NS, Rabiner EA, Gunn RN, Searle GE, Vora S, Litschge M, Kendro S, Cooper TB, Mathis CA, Laruelle M (2009) Positron emission tomography imaging of amphetamine-induced dopamine release in the human cortex: a comparative evaluation of the high affinity dopamine D2/3 radiotracers [11C]FLB 457 and [11C]fallypride. Synapse 63:447-461. CrossRef Medline

Narendran R, Lopresti BJ, Martinez D, Mason NS, Himes M, May MA, Daley DC, Price JC, Mathis CA, Frankle WG (2012) In vivo evidence for low striatal vesicular monoamine transporter 2 (VMAT2) availability in cocaine abusers. J Psychiatry 169:55-63. CrossRef Medline

Owen DR, Howell OW, Tang SP, Wells LA, Bennacef I, Bergstrom M, Gunn RN, Rabiner EA, Wilkins MR, Reynolds R, Matthews PM, Parker CA (2010) Two binding sites for $\left[{ }^{3} \mathrm{H}\right] \mathrm{PBR} 28$ in human brain: implications for TSPO PET imaging of neuroinflammation. J Cereb Blood Flow Metab 30:1608-1618. CrossRef Medline

Owen DR, Yeo AJ, Gunn RN, Song K, Wadsworth G, Lewis A, Rhodes C, Pulford DJ, Bennacef I, Parker CA, StJean PL, Cardon LR, Mooser VE, Matthews PM, Rabiner EA, Rubio JP (2012) An 18-kDa Translocator Protein (TSPO) polymorphism explains differences in binding affinity of the PET radioligand PBR28. J Cereb Blood Flow Metab 32:1-5. CrossRef Medline

Owen DR, Guo Q, Kalk NJ, Colasanti A, Kalogiannopoulou D, Dimber R, Lewis YL, Libri V, Barletta J, Ramada-Magalhaes J, Kamalakaran A, Nutt DJ, Passchier J, Matthews PM, Gunn RN, Rabiner EA (2014) Determination of [(11)C]PBR28 binding potential in vivo: a first human TSPO blocking study. J Cereb Blood Flow Metab 34:989-994. CrossRef Medline

Ryan LJ, Martone ME, Linder JC, Groves PM (1988) Cocaine, in contrast to D-amphetamine, does not cause axonal terminal degeneration in neostriatum and agranular frontal cortex of Long-Evans rats. Life Sci 43:14031409. CrossRef Medline

Sekine Y, Ouchi Y, Sugihara G, Takei N, Yoshikawa E, Nakamura K, Iwata Y, Tsuchiya KJ, Suda S, Suzuki K, Kawai M, Takebayashi K, Yamamoto S, Matsuzaki H, Ueki T, Mori N, Gold MS, Cadet JL (2008) Methamphetamine causes microglial activation in the brains of human abusers. J Neurosci 28:5756-5761. CrossRef Medline

Smith SM, Jenkinson M, Woolrich MW, Beckmann CF, Behrens TE, Johansen-Berg H, Bannister PR, De Luca M, Drobnjak I, Flitney DE, Niazy RK, Saunders J, Vickers J, Zhang Y, De Stefano N, Brady JM, Matthews PM (2004) Advances in functional and structural MR image analysis and implementation as FSL. Neuroimage 23 [Suppl 1]:S208-S219.

Thomas DM, Walker PD, Benjamins JA, Geddes TJ, Kuhn DM (2004) 
Methamphetamine neurotoxicity in dopamine nerve endings of the striatum is associated with microglial activation. J Pharmacol Exp Ther 311: 1-7. CrossRef Medline

Turkheimer FE, Edison P, Pavese N, Roncaroli F, Anderson AN, Hammers A, Gerhard A, Hinz R, Tai YF, Brooks DJ (2007) Reference and target region modeling of [11C]-(R)-PK11195 brain studies. J Nucl Med 48:158167. Medline

Venneti S, Wang G, Nguyen J, Wiley CA (2008) The positron emission tomography ligand DAA1 106 binds with high affinity to activated microglia in human neurological disorders. J Neuropathol Exp Neurol 67:10011010. CrossRef Medline

Venneti S, Lopresti BJ, Wiley CA (2013) Molecular imaging of microglia/ macrophages in the brain. Glia 61:10-23. CrossRef Medline

Volkow ND, Wang GJ, Fowler JS, Logan J, Hitzemannn R, Gatley SJ, MacGregor RR, Wolf AP (1996) Cocaine uptake is decreased in the brain of detoxified cocaine abusers. Neuropsychopharmacology 14:159168. CrossRef Medline
Volkow ND, Wang GJ, Fowler JS, Logan J, Gatley SJ, Hitzemann R, Chen AD, Dewey SL, Pappas N (1997) Decreased striatal dopaminergic responsiveness in detoxified cocaine-dependent subjects. Nature 386:830-833. CrossRef Medline

Volkow ND, Chang L, Wang GJ, Fowler JS, Leonido-Yee M, Franceschi D, Sedler MJ, Gatley SJ, Hitzemann R, Ding YS, Logan J, Wong C, Miller EN (2001) Association of dopamine transporter reduction with psychomotor impairment in methamphetamine abusers. Am J Psychiatry 158:377382. CrossRef Medline

Wang GJ, Volkow ND, Fowler JS, Fischman M, Foltin R, Abumrad NN, Logan J, Pappas NR (1997) Cocaine abusers do not show loss of dopamine transporters with age. Life Sci 61:1059-1065. CrossRef Medline

Yao H, Kim K, Duan M, Hayashi T, Guo M, Morgello S, Prat A, Wang J, Su TP, Buch S (2011) Cocaine hijacks sigmal receptor to initiate induction of activated leukocyte cell adhesion molecule: implication for increased monocyte adhesion and migration in the CNS. J Neurosci 31:5942-5955. CrossRef Medline 